\title{
PENGEMBANGAN PENDIDIKAN ISLAM BERBUDAYA NIRKEKERASAN
}

\author{
Adi Sudrajat \\ Universitas Islam Malang \\ adi.sud90@gmail.com
}

\begin{abstract}
Abstrak
Pendidikan merupakan alat untuk mencetak manusia yang humanis, cinta damai, dan juga solusi dari segala masalah, tapi banyak masalah muncul dari dunia pendidikan salah satunya kekerasan dalam pendidikan, ironisnya itu terjadi mulai dari tingakat dasar sampai perguruan tinggi, untuk menghadapi masalah ini perlu diadakan rivitalisasi pendidikan yaitu dengan mengembangkan pendidikan agama Islam berdudaya nirkekerasan. Ini sebagai tawaran solusi yang tepat untuk menyelesaikan masalah kekerasan yang terjadi didalam dunia pendidikan saat ini. Seperti apa yang di ajarkan oleh Nabi Muhammad SAW bagaiamana cara menanamkan nilai-nilai pendidikan yang humanis sehingga Islam menjadi agama rahmatan lilalamin.
\end{abstract}

Kata Kunci; pendidikan Islam, nirkekerasan

\section{Pendahuluan}

Banyak orang salah memahami risalah Islam yang bersifat universal dengan menyebarkan isu-isu negative tentang Islam. Mereka mengatakan bahwa Islam tersebar karena tajamnya pedang, tidak mengakui kebebasan beragama, berpendapat, dan berkebangsaan. Menurut mereka, jihad dalam Islam adalah media untuk menindas bangsa-bangsa dan umat lain, sehingga hubungan Islam dengan umat lain adalah hubungan permusuhan. Semua prasangka ini muncul boleh jadi karena ketidaktahuan akan hakikat damai dakwah Islam. Mereka memiliki pemahaman yang keliru tentang fakta-fakta sejarah dan interpretasi dangkal pada teks-teks hukum Islam.

Padahal, makna Islam itu sendiri dari segi bahasa, berakar pada kata salam yang berarti tunduk, patuh, dan damai. Artinya misi utama agama Islam adalah menciptakan keselamatan dan perdamaian bagi semesta alam (rahmatan li al-'alamin). Dengan kata lain, agama Islam yang disebarkan dan 
diajarkan oleh Nabi Muhammad saw merupakan agama yang ditujukan demi kesejahteraan dan keselamatan seluruh umat sekalian alam.

Pendidikan Agama Islam (PAI) yang memiliki fungsi sebagai media pembentukan akhlaq, etika, ataupun karakter peserta didik dapat dijadikan sebagai alternatif solusi untuk menanamkan budaya nilai-nilai nirkekerasan. Untuk itulah perlu dibahas lebih lanjut dalam makalah ini.

\section{Pengertian Pengembangan Pendidikan Agama Islam Berbudaya Nirkekerasan}

Sebelum mendefinisikan secara keseluruhan pengembangan Pendidikan Agama Islam berudaya nirkekerasan, perlu penulis sampaikan arti atau definisi dari masing-masing kata atau istilah yang merangkainya, yaitu pengembangan, pendidikan agama Islam, budaya, dan nirkekerasan. Dengan memahami makna dari kata-kata tersebut diharapkan dapat memberikan definisi secara utuh dan mendudukkannya secara benar.

Pertama, kata pengembangan. Menurut kamus pengembangan berarti "proses, cara, perbuatan mengembangkan." Kata tersebut merupakan satu akar dengan kata "berkembang" yang memiliki beberapa arti, yaitu (a) "mekar terbuka atau membentang (tentang barang yang berlipat atau kuncup)"; (b) berarti "menjadi besar (luas, banyak, dan sebagainya); memuai"; (c) berarti "menjadi bertambah sempurna (tentang pribadi, pikiran, pengetahuan, dan sebagainya)"; (d) berarti "menjadi banyak (merata, meluas, dan sebagainya)." ${ }^{1}$ Dengan demikian, yang dimaksud pengembangan di sini adalah suatu proses usaha yang dilakukan untuk menjadikan Pendidikan Agama Islam menjadi lebih baik atau lebih sempurna lagi dengan mengembangkan budaya nirkekerasan.

Kedua, kata pendidikan. Pengertian pendidikan yang cukup komprehensif adalah sebagaimana dijelaskan dalam Undang-undang Republik Indonesia Nomor 20 Tahun 2003 tentang Sistem Pendidikan Nasional pasal 1 ayat 1 adalah sebagai berikut:

"Pendidikan adalah usaha sadar dan terencana untuk mewujudkan suasana belajar dan proses pembelajaran agar peserta didik secara aktif mengembangkan potensi dirinya untuk memiliki kekuatan spiritual keagamaan, pengendalian diri, kepribadian, kecerdasan, akhlak mulia, serta keterampilan yang diperlukan dirinya, masyarakat, bangsa dan negara". ${ }^{2}$

\footnotetext{
${ }^{1}$ Kamus Besar Bahasa Indonesia Luar Jaringan (Luring), KBBI Offline Versi 1,3.

${ }^{2}$ Undang-undang Republik Indonesia Nomor 20 Tahun 2003 tentang Sistem Pendidikan Nasional pasal 1 ayat 1.
} 
Dengan demikian, Pendidikan Agama Islam dapat didefinisikan sebagai upaya sadar dan terencana dalam menyiapkan peserta didik untuk mengenal, memahami, menghayati, mengimani, bertakwa, berakhlak mulia, dan mengamalkan ajaran agama Islam dari sumber utamanya kitab suci Al-Quran dan Hadits, melalui kegiatan bimbingan, pengajaran, latihan, serta penggunaan pengalaman. Secara lebih ringkas, Zuhairini mendefinisikan Pendidikan Agama Islam sebagai "usaha-usaha secara sistematis dan pragmatis dalam membantu anak didik agar mereka hidup sesuai dengan ajaran Islam"3

Ketiga, kata budaya. Budaya adalah suatu cara hidup yang berkembang dan dimiliki bersama oleh sebuah kelompok orang, dan diwariskan dari generasi ke generasi. Budaya terbentuk dari banyak unsur yang rumit, termasuk sistem agama dan politik, adat istiadat, bahasa, perkakas, pakaian, bangunan, dan karya seni. Bahasa, sebagaimana juga budaya, merupakan bagian tak terpisahkan dari diri manusia sehingga banyak orang cenderung menganggapnya diwariskan secara genetis. Ketika seseorang berusaha berkomunikasi dengan orang-orang yang berbeda budaya, dan menyesuaikan perbedaan-perbedaannya, membuktikan bahwa budaya itu dipelajari. Budaya adalah suatu pola hidup menyeluruh, karena itu budaya bersifat kompleks, abstrak, dan luas. Banyak aspek budaya turut menentukan perilaku komunikatif. Unsur-unsur sosio-budaya ini tersebar, dan meliputi banyak kegiatan social manusia. ${ }^{4}$ Jadi berbudaya dalam tulisan ini artinya, peserta didik diharapkan memiliki suatu pola hidup yang berbasis pada nirkekerasan.

Keempat, kata nirkekerasan. Kata ini berasal dari kata dasar keras yang mendapat imbuhan "ke" dan akhiran "an" (kekerasan) dan diawali dengan kata "nir" yang berarti tidak atau bukan. ${ }^{5}$ Sehingga "nirkekerasan" secara bebas dapat diartikan tidak atau tanpa kekerasan. Kekerasan itu sendiri mempunyai arti (1) perihal (yang bersifat, berciri) keras; (2) perbuatan seseorang atau kelompok orang yg menyebabkan cedera atau matinya orang lain atau menyebabkan kerusakan fisik atau barang orang lain; (3) paksaan. ${ }^{6}$ Jadi secara bahasa nirkekerasan dapat diartikan sebagai perihal yang tidak hlm.27.

3ZZuhairini, dkk., Sejarah Pendidikan Islam, (Jakarta: Bumi Aksara, 2010),

${ }^{4}$ Deddy Mulyana dan Jalaluddin Rakhmat. Komunikasi Antarbudaya: Panduan Berkomunikasi dengan Orang-Orang Berbeda Budaya. (Bandung: Remaja Rosdakarya, 2006), hlm. 25.

${ }^{5} \mathrm{KBBI}$ Offline Versi $1,3$.

${ }^{6} \mathrm{KBBI}$ Offline Versi $1,3$. 
bersifat keras, tanpa adanya unsur paksaan, dan perbuatan yang tidak menimbulkan kerugian pada orang lain baik material maupun immaterial.

Lebih jelas lagi definisi nirkekerasan sebagaimana yang disampaikan oleh Mohammed Abu Nimer. Menurutnya, nirkekerasan adalah sekumpulan sikap, pandangan, dan aksi yang ditujukan untuk mengajak orang di pihak lain agar mengubah pendapat, pandangan, dan aksi mereka. Bagi pegiat nirkekerasan penggunaan cara-cara damai mutlak dilakukan untuk mencapai hasil yang damai. Oleh karenanya, para penganut nirkekerasan tidak membalas tindakan musuh mereka dengan kekerasan. Menurut Nimer aksi nirkekerasan memiliki lima ciri utama, yaitu (a) secara lahir tidak agresif, tetapi tetap menampakkan kedinamisan; (b) tidak berusaha untuk menistakan musuh tetapi mengajak musuh untuk berubah lewat pemahaman dan kesadaran baru tentang cipta-damai; (c) ditujukan kepada kekuatan kejahatan, bukan kepada orang-orang yang terperangkap dalam kekuatan tersebut; (d) nirkekerasan berupaya untuk menghindari bukan hanya kekerasan lahiriah, tapi juga kekerasan batiniah; (e) nirkekerasan didasarkan atas pendirian bahwa alam semesta berpihak pada keadilan. ${ }^{7}$

Dari penjelasan tersebut di atas, pengembangan Pendidikan Agama Islam berbudaya nirkekerasan dapat dipahami sebagai sebuah upaya pengembangan secara sistematis dalam membantu pesertadidik agar mereka hidup sesuai dengan ajaran Islam dan memiliki pola hidup (budaya) yang senantiasa menebarkan kedamaian (nirkekerasan) berdasarkan ajaran Islam yang rahmatan lil 'alamin.

\section{Nilai-Nilai Nirkekerasan dalam Ajaran Islam}

Islam sebagai agama (al-dīn) paripurna merupakan cara hidup yang menyeluruh mencakup seluruh bidang aktivitas manusia. Di dalam Islam tentu terdapat berbagai ajaran untuk dapat mengantarkan manusia hidup damai tanpa adanya kekerasan sebagaimana tujuan diutusnya Nabi Muhammad sebagai pembawa rahmat bagi semesta alam. Dalam Islam, gagasan untuk menciptakan perdamaian terdapat dua istilah Arab yang biasa digunakan, yaitu salam yang berarti ketenangan dan keselamatan, dan sulh yang berarti genjatan senjata atau perjanjian penghentian peperangan untuk suatu waktu atau berarti menunjukkan berakhirnya perang. ${ }^{8}$ Terdapat

\footnotetext{
${ }^{7}$ Mohammed Abu Nimer, Nirkekerasan dan Bina-Damai dalam Islam: Reori dan Praktik. Terj. M. Irsyad Rhafsadi dan Khairil Azhar Edisi Digital (Jakarta: Democrasy Project, Yayasan Abad Demokrasi, 201), hlm. 20.

${ }^{8}$ Bernard Lewis, The Political Language of Islam, (Chicago: The University of Chicago Press, 1991), hlm. 78-79.
} 
beberapa ayat al-Qur'an dan Hadith Nabi (praktik kehidupan Nabi) yang mengandung ajaran nirkekerasan atau terciptanya perdamaian.

Sebagai awal perlu penulis sampaikan sebuah ayat al-Qur'an yang sering dikutip berkenaan dengan Islam dan nirkekerasan sebagai berikut.

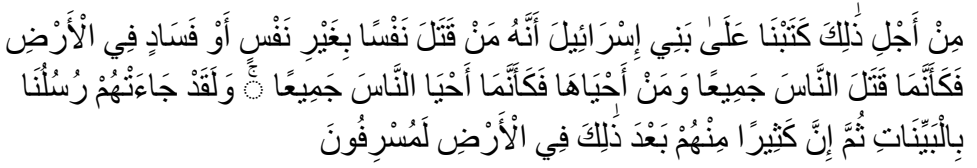

"Oleh karena itu Kami tetapkan (suatu hukum) bagi Bani Israil, bahwa: Barangsiapa yang membunuh seorang manusia, bukan karena orang itu (membunuh) orang lain, atau bukan karena membuat kerusakan dimuka bumi, Maka seakan-akan Dia telah membunuh manusia seluruhnya. dan Barangsiapa yang memelihara kehidupan seorang manusia, Maka seolah-olah Dia telah memelihara kehidupan manusia semuanya. dan Sesungguhnya telah datang kepada mereka Rasul-rasul Kami dengan (membawa) keterangan-keterangan yang jelas, kemudian banyak diantara mereka sesudah itu sungguhsungguh melampaui batas dalam berbuat kerusakan dimuka bumi". 9

Ayat ini menurut Chaiwat Satha-Anand merupakan ayat yang komplek dan sangat menarik karena memuat seputar kekerasan dan nirkekerasan dalam Islam. ${ }^{10}$ Dari ayat ini setidaknya dapat kita analisa beberapa hal. Pertama, meskipun membunuh atau memelihara satu nyawa sama-sama berdampak pada segenap umat manusia, tetapi bobotnya tidak sama antara "qatala nafsan (pembunuhan)" dan "ahyāhā (memelihara kehidupan)". Dalam ayat tersebut sangat jelas bahwa Allah menetapkan syarat bolehnya tindakan pembunuhan hanya boleh dilakukan apabila yang terbunuh telah melakukan pembunuhan ${ }^{11}$ atau berbuat kerusakan di muka bumi. Dua syarat ini merupakan dua dosa terberat dalam Islam. Sementara itu, perintah memelihara kehidupan tidak bersyarat. Dengan demikian, dapat dikatakan

\footnotetext{
${ }^{9}$ QS. al-Maidah (5): 32. Ayat al-Qur'an dan terjemahnya diambil dari aplikasi Qur'an in Word.

${ }^{10}$ Chaiwat Satha-Anand, Barangsiapa Memelihara Kehidupan...: Esai-esai tentang Nirkekerasan dan Kewajiban Islam, terj. Taufik Adnan Amal, Pradewi Tri Chatami, Irsyad Rafsadi (Jakarta: PUSAD Paramadina, 2015), hlm. 7.

${ }^{11}$ Dalam fiqih dikenal dengan istilah qișāṣ.
} 
bahwa memelihara kehidupan, yang tak bersyarat, jauh lebih utama ketimbang mengambil nyawa dengan syarat yang berat. ${ }^{12}$

Kedua, teka-teki di balik ayat ini, yaitu bagaimana mungkin membunuh atau memelihara satu jiwa/nyawa disetarakan dengan membunuh atau memelihara segenap manusia? Hal ini menunjukkan problem kuantifikasi yang luar biasa dalam satu nyawa manusia. Ini menjadi prinsip penting bagi nirkekerasan dalam Islam. Menurut ayat tersebut nyawa seorang manusia disetarakan dengan nyawa seluruh umat manusia dan oleh karena itu, siapa pun hampir mustahil mengambil satu nyawa manusia kecuali dengan itu dia siap menghabisi segenap manusia. Menurut Shata-Anand, untuk dapat memaknai kuantifikasi nyawa manusia semacam ini, perlu menafsirkan nyawa di dalam "jejaring keterhubungan" dengan seluruh umat manusia. Dengan seperti itu, satu nyawa dimungkinkan setara dengan segenap nyawa karena dari sudut pandang semesta. ${ }^{13}$ Sebagai perbandingan adalah seperti ketika seseorang melihat sebutir pasir yang memuat sejarah hidup planet bumi. Menyetarakan satu nyawa dengan segenap nyawa umat manusia berarti juga, di antaranya, memandang orang lain sebagai sebuah dunia tersendiri, dan melihat diri sendiri di dunia lain itu, terutama ketika "yang lain" itu menjadi "musuh". Dengan cara pandang demikianlah, menyelamatkan satu nyawa dapat dipahami sebagai menyelamatkan nyawa segenap manusia. ${ }^{14}$

Dari penjelasan ayat tersebut dapat diambil satu nilai penting untuk nirkekerasan, yaitu pemuliaan atau penghargaan yang tinggi terhadap kehidupan manusia, satu nyawa disetarakan dengan semua nyawa manusia. Menyakiti apalagi membunuh satu jiwa berarti menyakiti atau membunuh semua manusia, demikian juga sebaliknya membiarkan satu jiwa manusia untuk dapat hidup dengan damai berarti seakan-akan telah "menghidupkan" semua jiwa manusia.

Selanjutnya perlu dikemukakan di sini dua persitiwa penting dalam sejarah kehidupan Nabi karena mengandung nilai-nilai nirkekerasan untuk terciptanya hidup yang damai. Kedua peristiwa itu adalah membangun kembali Ka'bah dan peristiwa fathu Makkah. ${ }^{15}$

\footnotetext{
${ }^{12}$ Shata-Anand, Barangsiapa Memelihara Kehidupan., hlm. 7.

${ }^{13}$ Allah memandang bahwa membunuh seseorang itu adalah sebagai membunuh manusia seluruhnya, karena orang seorang itu adalah anggota masyarakat dan karena membunuh seseorang berarti juga membunuh keturunannya.

${ }^{14}$ Shata-Anand, Barangsiapa Memelihara Kehidupan., hlm. 8-9.

${ }^{15}$ Kedua peristiwa tersebut memiliki latar yang berbeda. Peristiwa pertama terjadi sebelum Muhammad mendapatkan risalah dari Allah swt, dan karenanya dia dipandang sebagai orang biasa yang tidak memiliki kekuasaan baik
} 
Ketika Nabi Muhammad berusia 35tahun tepatnya pada tahun $605 \mathrm{M}$, masyarakat Mekkah membangun kembali Ka`bah yang rusak karena kejadian banjir besar melanda kota Mekkah. Sebagai peninggalan nenek moyang mereka, Nabi Ibrahim, Ka'bah merupakan simbul atau tempat yang "disucikan" oleh suku-suku di sekitar Mekkah. Karena itu, mereka bahu membahu membangunnya kembali dengan masing-masing suku mengumpulkan batu untuk meninggikan bangunan Ka'bah. ${ }^{16}$

Perselisihan terjadi di antara suku-suku tersebut ketika akan meletakkan hajar aswad di salah satu sudut bangunan Ka'bah. Setiap suku mempunyai keinginan yang sama untuk mengangkat dan meletakkan hajar aswad di tempatnya. Masing-masing suku tidak ada yang mau mengalah dan membiarkan suku lain yang mengerjakan hal itu sehingga terjadilah kebuntuan yang berlangsung sampai empat atau lima hari dan mereka telah bersiap-siap bertarung untuk menyelesaikan pertikaian tersebut. ${ }^{17}$

Melihat situasi panas tersebut, salah satu tokoh Qurasy, Abū Umayyah bin al-Mughirah paman Khālid bin al-Walīd mengusulkan satu solusi untuk menyelesaikan pertikaian tersebut. Usulannya adalah agar semua suku mengikuti oleh orang yang memasuki komplek Ka'bah melalui gerbang "bab $a l-s ̦ \bar{a} f \bar{a}$ ". Semua pihak sepakat terhadap usulan tersebut. Dan ternyata orang memasuki komplek Ka 'bah melalui gerbang "bab al-șāfā" adalah Muhammad yang mereka kenal sebagai orang yang dapat dipercaya sehingga mendapat julukan al-amin. Karena itu, semua suku senang dan sepakat menyelesaikan pertikaian mereka kepada Muhammad. ${ }^{18}$

Dari peristiwa ini, dapat diidentifikasi beberapa nilai nirkekerasan untuk menciptakan perdamaian. Pertama adalah nilai kesabaran yang ditunjukkan oleh Nabi dengan mau mendengar terlebih dahulu permasalahan yang terjadi. Tindakan mendengarkan ini menandakan kesabaran Nabi dan kehendaknya untuk mempelajari semua informasi yang didapatnya sebelum mengambil keputusan. Kedua adalah nilai penghormatan kemanusiaan seluruh kelompok. Nilai ini dapat dipahami dari tindakannya mengajak semua pemimpin kelompok untuk memegang pinggiran jubah guna mengangkat hajar aswad bersama-sama. Dengan peristiwa ini, Nabi menegaskan bahwa

politik maupun agama, tepatnya pada tahun $605 \mathrm{M}$. Sedangkan peristiwa kedua terjadi setelah Nabi Muhammad tinggal di Madinah karena hijrah dan bersama para pengikutnya sekitar 10.000 orang kembali ke Mekkah. Pada peristiwa ini tentunya Nabi Muhammad memiliki kekuasaan yang besar baik secara politik maupun agama. Lihat ShataAnand, Barangsiapa Memelihara Kehidupan., hlm. 64-66.

${ }^{16}$ Pada saat itu Ka'bah tegak tanpa atap dan hanya sedikit lebih tinggi dari tubuh manusia.

${ }^{17}$ Shata-Anand, Barangsiapa Memelihara Kehidupan., hlm. 66-67.

${ }^{18}$ Ibid. 
semua kelompok memiliki signifikansi dan martabat yang sama. Kehormatan tidak harus diperoleh dengan mengorbankan kehormatan kelompok lain atau dengan menggunakan cara-cara kekerasan, tetapi dapat dibagi dan diraih bersama. Dari peristiwa itu juga dapat diidentifikasi nilai nirkekerasan yang ketiga yaitu nilai berbagi dengan sesama. Berbagi bersama ini akan terjadi dengan adanya partisipasi yang sama di antara kelompok-kelompok yang bertikai. Keempat adalah nilai berpikir kreatif yang ditandai dengan penggunaan jubbah secara inovatif sebagai sarana bersama untuk samasama berperan sehingga tidak ada satupun kelompok yang merasa ditinggalkan, dan dengan seperti itu selesailah konflik tersebut. ${ }^{19}$

Peristiwa kedua adalah fat makkah. Peristiwa ini terjadi 8 tahun setelah hijrah Nabi ke Madinah. Hijrah ke Madinah dilakukan Nabi dan para Sahabatnya karena pada saat itu mereka mendapat ancaman dan bahkan siksaan dari orang-orang kafir Mekkah yang berkuasa. Karena itu, pada tahun $622 \mathrm{H}$ Nabi memimpin kaum Muslimin melakukan hijrah dari Mekkah ke Madinah. Setelah delapan tahun tinggal di Madinah dengan perolehan prestasi-prestasi gemilang dalam kehidupan politik dan kemasyarakatan kaum Muslimin, Nabi kembali ke Mekkah bersama 10.000 orang yang mengikutinya. Peristiwa kembalinya Nabi ke kota Mekkah ini kemudian dikenal dengan istilah fath makkah.

Orang-orang kafir Mekkah yang sebelumnya banyak berbuat kesalahan bahkan penyiksaan kepada para pengikut Muslim, merasa takut terhadap aksi balas dendam yang mungkin akan mereka lakukan. Tetapi, ketika rombongan Nabi memasuki kota Mekkah, tidak ada satupun peristiwa kekerasan yang mereka lakukan. Bahkan pada saat itu Nabi Muhammad menegaskan tidak akan ada celaan dan hinaan apalagi balas dendam terhadap penduduk Mekkah. Beliau menyampaikan salah satu ayat al-Qur'an sebagai berikut:

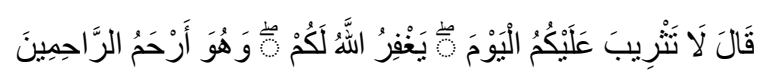

"Dia (Yusuf) berkata: "Pada hari ini tak ada cercaan terhadap kamu, Mudah-mudahan Allah mengampuni (kamu), dan Dia adalah Maha Penyayang diantara Para Penyayang".20

Dari peristiwa fath Makkah tersebut dapat diidentifikasi nilai yang sangat penting bagi terwujudnya nirkekerasan, yaitu nilai pemaafan. Tidak terjadinya kekerasan atau balas dendam yang dilakukan oleh kaum Muslimin pada saat itu walaupun mereka memiliki kekuatan dan kekuasaan yang besar

${ }^{19}$ Shata-Anand, Barangsiapa Memelihara Kehidupan., hlm. 68.

${ }^{20}$ QS. Yusuf (12): 92 
tidak lain adalah buah dari sikap kepemaafan Nabi yang memancar kepada seluruh kaum Muslimin. Pola perilaku Nabi yang mencerminkan sifat kepemaafan yang tinggi ini merupakan suatu manifestasi dari ajaran-ajaran Wahyu Tuhan. Hal ini ditegaskan oleh Allah swt dalam beberapa ayat-Nya sebagai berikut:

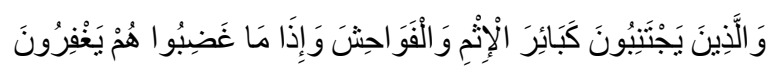

"Dan (bagi) orang-orang yang menjauhi dosa-dosa besar dan perbuatan- perbuatan keji, dan apabila mereka marah mereka memberi maaf". ${ }^{21}$

Dalam ayat ini dapat dipahami bahwa perbuatan memaafkan merupakan kewajiban kaum Muslimin, bahkan walaupun mereka dalam keadaan marah. Dalam ayat yang lain Allah berfirman:

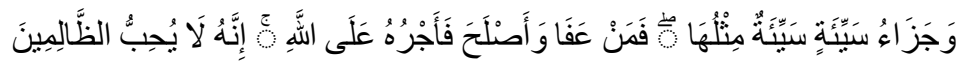

"Dan Balasan suatu kejahatan adalah kejahatan yang serupa,

Maka barang siapa memaafkan dan berbuat baik Maka pahalanya atas (tanggungan) Allah. Sesungguhnya Dia tidak menyukai orang-orang yang zalim." ${ }^{\prime 22}$

Menurut ayat ini, pemberian maaf dan rekonsiliasi (iș/āḥ) adalah tindakan tepat dalam situasi politik. Islam meyakini bahwa setiap orang pasti mampu memberi maaf terhadap kesalahan orang lain, karena itu al-Qur'an menganjurkannya.

Dari beberapa ayat dan peristiwa yang dilakukan Nabi Muhammad tersebut di atas dapat diidentifikasi beberapa nilai nirkekerasan yaitu: (a) pemuliaan atau penghargaan yang tinggi terhadap kehidupan manusia; (b) kesabaran; (c) penghormatan atas kemanusiaan; (d) berbagi bersama; (e) kreatifitas; dan (f) memaafkan.

\section{Urgensi dan Upaya Pengembangan Pendidikan Agama Islam Berbudaya Nirkekerasan}

Terjadinya tindak kekerasan di beberapa lembaga pendidikan dalam beberapa waktu yang lalu, mengagetkan banyak orang karena itu berarti ironi pendidikan, yaitu kejahatan seksual di Jakarta International School (JIS) dan kematian mahasiswa Sekolah Tinggi Ilmu Pelayaran (STIP). Sebagian pengamat pendidikan mengatakan bahwa kasus kekerasan ini merupakan lampu kuning dunia pendidikan Indonesia. Bahkan, Ketua Departemen Pendidikan dan Kebudayaan Nilai-nilai Kejuangan 45 Darmaningtyas

${ }^{21}$ QS. Asy-Syuraa (42): 37

${ }^{22}$ QS. Asy-Syuraa (42): 40 
mengaku takut jika pendidikan Indonesia bakal mereproduksi budaya kekerasan. ${ }^{23}$

Menurut Direktur Pendidikan Madrasah M. Nur Kholis Setiawan, pendalaman nilai keislaman melalui empat mata pelajaran rumpun Pendidikan Agama Islam (PAI) di madrasah menjadi salah satu piranti antisipatif akan kekhawatiran lembaga pendidikan yang mereproduksi kekerasan. "Empat mapel PAl adalah piranti astisipatif atas kekhawatiran lembaga pendidikan mereproduksi kekerasan,". ${ }^{24}$

$\mathrm{Di}$ samping kekhawatiran lembaga pendidikan mereproduksi kekerasan, Pendidikan Agama Islam (PAI) berbudaya nirkekerasan penting ditawarkan antara lain karena ada kecenderungan bahwa para penganut agama bersikap intoleran terhadap penganut agama lainnya, eksklusif, egois, closeminded, dan berorientasi pada kesalehan individu. Oleh karena itu, dirasa perlu dimulai adanya perubahan paradigma pendidikan dalam PAI. PAI tidak hanya menggunakan paradigma learning to know, to do dan to be, tetapi juga to live together. ${ }^{25}$

Pendidikan Agama Islam sebagai sebuah mata pelajaran menjadi bagian yang tidak terpisahkan dari kurikulum suatu sekolah/madrasah. Jadi bisa dikatakan bahwa Pendidikan Agama Islam dapat dijadikan sebagai media yang digunakan untuk mencapai aspek tujuan dan fungsi pendidikan di sekolah/madrasah, termasuk dapat dijadikan sebagai media yang digunakan untuk merealisasikan tujuan dan fungsi pendidikan berbudaya nirkekerasan. ${ }^{26}$

Untuk merealisasikannya, guru Pendidikan Agama Islam dapat mengintegrasikan nilai-nilai nirkekerasan ajaran Islam ke dalam pembelajaran PAI. Nilai-nilai nirkekerasan tersebut sebagaimana kajian di atas adalah (a) pemuliaan atau penghargaan yang tinggi terhadap kehidupan manusia; (b) kesabaran; (c) penghormatan atas kemanusiaan; (d) berbagi bersama; (e) kreatifitas; dan (f) memaafkan.

Selanjutnya, perlu dikemukakan beberapa asumsi filosofis pendidikan berbudaya nirkekerasan itu sendiri yang penulis pahami dari pengembangan pendidikan berbasis multikultural yang memang berkembang lebih dahulu. Pertama, Pendidikan Agama Islam berbudaya nirkekerasan harus berpijak pada pandangan yang lebih luas mengenai pendidikan sebagai transmisi

${ }^{23}$ Diambil dari website kemenag pada tanggal 25 Desember 2015: http://www.kemenag.go.id/index.php?a=berita\&id=188554.

${ }^{24}$ Ibid.

${ }^{25}$ Kasinyo Harto, "Membangun Pola Pembelajaran Pendidikan Agama Yang Berwawasan Multikultural", Conciencia, Vol. 1 No. 2 (2007), hlm. 25.

${ }^{26}$ Erwin Yudi Prahara, Materi Pendidikan Agama Islam, (Ponorogo: STAIN Ponorogo Press, 2009), hlm. 5-6 
kebudayaan. Artinya, pengembangan Pendidikan Agama Islam berbudaya nirkekerasan tidak hanya menjadi tanggung jawab guru agama saja, tetapi menjadi tanggung jawab bersama banyak pihak terkait. Kedua, program pengembangan Pendidikan Agama Islam berbudaya nirkekerasan diharapkan menghindari kecenderungan memandang peserta didik secara stereotip menurut identitas etnik mereka dan meningkatkan eksplorasi pemahaman yang lebih besar mengenai kesamaan dan perbedaan di kalangan peserta didik dari berbagai kelompok etnik. Dengan seperti itu diharapkan tidak lagi muncul konflik kekerasan karena perasaan beda kelompok. ${ }^{27}$

\section{Penutup}

Pengembangan Pendidikan Agama Islam berbudaya nirkekerasan dapat dipahami sebagai sebuah upaya pengembangan secara sistematis dalam membantu peserta didik agar mereka hidup sesuai dengan ajaran Islam dan memiliki pola hidup (budaya) yang senantiasa menebarkan kedamaian (nirkekerasan) berdasarkan ajaran Islam yang rahmatan lil ‘alamin.

Dari beberapa ayat dan peristiwa yang dilakukan Nabi Muhammad yang telah dilakukan kajian di atas dapat diidentifikasi beberapa nilai nirkekerasan yaitu: (a) pemuliaan atau penghargaan yang tinggi terhadap kehidupan manusia; (b) kesabaran; (c) penghormatan atas kemanusiaan; (d) berbagi bersama; (e) kreatifitas; dan (f) memaafkan.

Pendidikan Agama Islam (PAI) diharapkan dapat menjadi salah satu piranti antisipatif akan kekhawatiran lembaga pendidikan yang mereproduksi kekerasan. Di samping itu, pengembangan PAI berbudaya nirkekerasan penting ditawarkan antara lain mengimbangi adanya kecenderungan bahwa para penganut agama bersikap intoleran terhadap penganut agama lainnya, eksklusif, egois, close-minded, dan berorientasi pada kesalehan individu. Perubahan paradigma pendidikan dalam PAI yang tidak hanya learning to know, to do dan to be, tetapi juga to live together. Pendidikan Agama Islam dapat dijadikan sebagai media merealisasikan tujuan dan fungsi pendidikan berbudaya nirkekerasan yang secara filosofis menjadi tanggung jawab bersama berbagai pihak terutama di kalangan peserta didik dari berbagai kelompok etnik.

${ }^{27}$ Gwendolyn C. Baker, Planing and Organizing for Multicultural Instruction (California: Addison-Wesley Publishing Company, 1994), 25-26. 


\section{Daftar Rujukan}

Al-Qur'an dan terjemahnya dalam aplikasi Qur'an in Word.

Bernard Lewis, The Political Language of Islam, Chicago: The University of Chicago Press, 1991.

C. Baker, Gwendolyn, Planing and Organizing for Multicultural Instruction, California: Addison-Wesley Publishing Company, 1994.

Harto, Kasinyo, "Membangun Pola Pembelajaran Pendidikan Agama Yang Berwawasan Multikultural", Conciencia, Vol. 1 No. 22007.

http://www.kemenag.go.id/index.php?a=berita\&id=188554.

Kamus Besar Bahasa Indonesia Luar Jaringan (Luring), KBBI Offline Versi 1,3.

Mohammed Abu Nimer, Nirkekerasan dan Bina-Damai dalam Islam: Reori dan Praktik. Terj. M. Irsyad Rhafsadi dan Khairil Azhar Edisi Digital, Jakarta: Democrasy Project Yayasan Abad Demokrasi, 2010.

Mulyana, Deddy dan Jalaluddin Rakhmat, Komunikasi Antarbudaya: Panduan Berkomunikasi dengan Orang-Orang Berbeda Budaya, Bandung: Remaja Rosdakarya, 2006.

Satha-Anand, Chaiwat. Barangsiapa Memelihara Kehidupan...: Esai-esai tentang Nirkekerasan dan Kewajiban Islam,terj. Taufik Adnan Amal, Pradewi Tri Chatami, Irsyad Rafsadi (Jakarta: PUSAD Paramadina, 2015)

Undang-undang Republik Indonesia Nomor 20 Tahun 2003 tentang Sistem Pendidikan Nasional.

Yudi Prahara, Erwin. Materi Pendidikan Agama Islam, Ponorogo: STAIN Ponorogo Press, 2009.

Zuhairini, dkk., Sejarah Pendidikan Islam, Jakarta: Bumi Aksara, 2010. 